\title{
The Mediating Role of Mushroom Management Within the Impact of Job Stress on Intention to Leave
}

\author{
Mustafa Kemal KÜLEKCI iD a Onur Başar ÖZBOZKURT iD b Emel BAHAR iD c \\ a Faculty of Technology, Tarsus University, Mersin, Turkey. mkkulekci@tarsus.edu.tr \\ b Higher Vocational School, Tarsus University, Mersin, Turkey. onurozbozkurt@tarsus.edu.tr \\ ‘ Higher Vocational School, Tarsus University, Mersin, Turkey. ebahar@tarsus.edu.tr
}

\begin{tabular}{|c|c|}
\hline ARTICLE INFO & ABSTRACT \\
\hline $\begin{array}{l}\text { Keywords: } \\
\text { Job stress } \\
\text { Intention to leave } \\
\text { Mushroom management style } \\
\text { Mediating role }\end{array}$ & $\begin{array}{l}\text { Purpose-Mushroom management style which refers to being kept of the employees in the dark like } \\
\text { mushroom cultivation and given them inadequate information to increase their performance, has } \\
\text { been considerably drawn attention as a rising metaphor in the few years for management science. } \\
\text { Since there are limited mushroom management studies and none of them quantitatively being } \\
\text { investigated, the present study aims at being fulfilled the research gap via exploring the mediating } \\
\text { role played by mushroom management style within the impact of job stress on intention to leave } \\
\text { which have a great impact on the management of organizations. }\end{array}$ \\
\hline $\begin{array}{l}\text { Received } 30 \text { December } 2019 \\
\text { Revised } 7 \text { February } 2020 \\
\text { Accepted } 10 \text { February } 2020\end{array}$ & $\begin{array}{l}\text { Design/methodology/approach - Based on the purpose, the focus of this paper is on the private } \\
\text { healthcare sector due to the centralized and hierarchical structure, and being intensely exposed to } \\
\text { job stress. From this point of view, the questionnaire has been applied to } 221 \text { employees working at } \\
\text { the four private hospitals and the data obtained from the questionnaire has been analyzed via "SPSS } \\
22.0^{\prime \prime} \text {. }\end{array}$ \\
\hline \multirow[t]{2}{*}{$\begin{array}{l}\text { Article Classification: } \\
\text { Research Article }\end{array}$} & $\begin{array}{l}\text { Findings - As a result of the analysis, it has been indicated that the job stress has a significant effect } \\
\text { on intention to leave; the mushroom management has a statistically significant effect on both job } \\
\text { stress and intention to leave, and the mushroom management has a mediating role on within the } \\
\text { impact of job stress on intention to leave. }\end{array}$ \\
\hline & $\begin{array}{l}\text { Discussion - It has been recommended that managers should pay more attention to encouraging } \\
\text { effective and operative communication throughout the organization and regularly share more } \\
\text { information with the employee since they have a significant role in achieving organizational goals; } \\
\text { namely, effectiveness. }\end{array}$ \\
\hline
\end{tabular}

\section{INTRODUCTION}

Organizations struggle to preserve talent and find out better methods by which the quantity and quality of the attachment of employees with their can be improved in the competitive business environment (Gupta \& Shaheen, 2017: 136; Özbozkurt \& Özbozkurt, 2019: 308). However, the employees suffer encumber or load of works sometimes in such a competitive and firm environment of the organization and this milieu generates stress among employees that occurs for several reasons (Zahra, Khan, Imran, Aman \& Ali, 2018: 2). Taking into consideration of this, job stress is traditionally described as the destructive physical and emotional reactions that appear when the demands of the job exceed the requirements, resources or capabilities of the employer (Mohajan, 2012: 17) and it occurs when employees face work overload, time pressures, poor physical working conditions (Michie, 2002: 68). Moreover, it causes both employee health and employee's intention to leave from current organization ( $\mathrm{Lu}, \mathrm{Hu}$, Huang, Zhuang, Guo, Feng, Hu, Chen, Zou \& Hao, 2017: 2) and in this sense, employee's intention to leave is described as the process that can be voluntary; clearly, employees intend to leave the organization, or involuntary; in other words, managers make employees redundant (Mosadeghrad, 2013: 169).

On the other hand, in management science, the concept of mushroom management has been regarded in the last years and is affected by raising mushrooms. Just as mushrooms are cultivated, fertilized, and left in the dark in a short time; mushroom managers do not share the revenues, policies, and processes of the organization and business risks with employees; besides providing allow the necessary business resources to

\section{Önerilen Atıf/Suggested Citation}

Külekci, M. K., Özbozkurt, O. B., Bahar, E. (2020). The Mediating Role of Mushroom Management Within the Impact of Job Stress on Intention to Leave, Journal of Business Research-Turk, 12 (1), 361-371. 
them (Kılıç \& Olgun, 2017: 106). Precisely, managers commonly cannot acknowledge being interrogated and criticized by employees via continuing to keep their dominance and information in this kind of management (Tekin \& Birincioğlu, 2017: 22).

Although myriad studies are concentrating on the relationship between job stress and intention to leave, it has been seen that none of these studies quantitatively investigated the mediating role played by mushroom management style within the impact of job stress on intention to leave and the present study aims at fulfilling the research gap in the related literature. Based on the purpose of the research, the private healthcare sector owing to centralized and a sharp hierarchical structure, and intensely exposure to job stress is at the core of this study. From this point of view, the questionnaire has been applied to 221 employees working at the four private hospitals, Tarsus, Mersin. In this respect, the data obtained from the questionnaire has been analyzed via “SPSS 22.0" programme.

\section{THEORETICAL FRAMEWORK}

\subsection{Job Stress}

Stress is a widespread phenomenon all around during all human lifespan (Akanji, 2013: 73; Shahsavarani, Azad Marz Abadi \& Hakimi Kalkhoran, 2015: 230; Da Costa \& Pinto, 2017: 1; Abbasi, 2018: 1-2) and the questions of the causes or sources of job stress have attracted noticeable empirical attention and public fascination for last decades (Barling, Kelloway \& Frone, 2004: 3; Yan \& Xie, 2016: 306). In this respect, job stress has been explained in various ways over the years and it's generally called workplace stress or occupational stress and it was determined as the pressure from the environment an employee gets (Harshana, 2018: 59).

The contemporary definition of job-related stress all approves that stress emerges when there is a dissonance between the abilities and resources of the employee perception and the demands of the job (Blaug, Kenyon \& Lekhi, 2007: 4). In other words, job stress is assumed as a physical and psychological state that results when the resources of the individual are inadequate to overcome the pressures and demands of the job (Ratnawat \& Jha, 2014: 1; Rengin, 2018: 6). Likewise, job stress usually refers to as the destructive emotional and physical reactions that happen when the demands of the job exceed the needs, resources or capabilities of the employer (Mohajan, 2012: 17).

Akanji (2013: 73) considerably presumed that stress is remarked in terms of general psychological and physiological responses that provoke adversarial physical or mental health circumstances when an employe's adaptive capabilities are overextended. Therefore, job stress is understandably defined as happening when there are discrepancies between the physiological demands within a workplace and the inability of employees to either manage or overcome such work demands. In this sense, Munisamy (2013: 24) briefly states that stress consists of psychological and physiological reactions to excessive and commonly unpleasant stimulation and threatening events in the environment.

Besides, job stress is emphasized as depression, irritability, anxiety, angst, strain one's faces in his organization when he is overloaded with copious demands and expectations which he/she has to complete within a limited time-frame (Burman \& Goswami, 2018: 112). In this sense, the stress-induced owing to job performed by employees at organization has been a vital organizational stressor (Manjunatha \& Renukamurthy, 2017: 206) and it is a causal agent in both mental and physical disorders as well as organizational outcomes such as absenteeism and reduced productivity has gained widespread acceptance (Ganster \& Schaubroeck, 1991: 235). Similarly, stress has a destructive effect on employees' physical and mental health as well as influencing financial outputs and performance of the organizations. Accordingly, it becomes relevant to investigate underlying factors (i.e. stressors) and consider possible ways to minimize strain and reduce the costs for organizations (Atterwall \& Engqvist, 2016: 2).

On the other hand, employees who are exposed to high-level job stress can exhibit unpredictable behavior and attitudes towards the organization. It leads to employees who are limited to their performance in the organization to voluntarily leave their job (Gök, Akgündüz \& Alkan, 2017: 23). Namely, the problems facing in the organizations such as low salaries, advancement prospect, poor management, inflexible working hours or schedule, etc. create job stress; thus, it causes employee's intention to leave (Ramamurthi, Vakilbashi, Rashid, Mokhber \& Basiruddin, 2016: 529). 


\subsection{Intention to Leave}

Employees are the keystone of all organizations particularly the service-based organization whereby employees are the fundamental resources of the organization to drive the organization's business operations. Owing to the nature of business life, the employees face several challenges, and job stress negatively affects them to leave the current company (Ramamurthi et. al, 2016: 528). In this regard, employees' intention to leave is a critical and crucial concern that almost all of the organizations seem to face at one point or another (Treglown, Zivkov, Zarola \& Furnham, 2018: 1) and it focuses on leaving the organization as a workplace, and not on leaving the work sector or profession in general and refers to voluntary turnover (Appollis, 2010: 23; Gaudenz, De Geest, Schwendimann \& Zúñiga, 2017: 5).

Worku, Feleke, Debie \& Nigusie (2019: 1) stress that intention to leave is the leaving plan of an employee from their current organization soon due to several reasons. Additionally, Kashmoola, Ahmad \& Kheng (2017: 5) highlight that intention to leave can voluntarily occur from the organization or occupation and the stimuli of intention to leave the organization can be characterized as individual and organizational. Precisely, Tett \& Meyer (1993: 262) assume that intention to leave was conceived to be a conscious and deliberate willfulness to leave the organization. In other words, Radzi, Ramley, Salehuddin, Othman \& Jalis (2009: 173) point out that it commonly means an individual's perceived probability of leaving an employing organization, or the willingness of an individual to voluntarily as permanently withdraw from the organization.

Taking into consideration of the statements above, Liu, Zhu, Wu \& Mao (2019: 1) have found in their study that the job stress has a positive effect on employees of the healthcare sector. Furthermore, Lo, Chien, Hwang, Huang \& Chiou (2018: 679)'s study on the healthcare sector indicates that job stress has a significant impact on the mood of employees which in turn affects employees' intention to leave the hospital even their profession. In this regard, the following hypothesis is proposed:

$H_{1}$ : Job stress has a positive impact on intention to leave.

\subsection{Mushroom Management}

The mushroom management approach has been actively initiated to use in the literature as a reflection of the metaphoric perception of mushroom cultivation to management sciences (Şener \& Gündüzalp, 2019: 793). In other words, mushroom management is seen as a theory that emerged as a metaphor that highlights the managers keep the employees in the dark like mushroom cultivation and give them resources only they need via thinking of increasing their performance (Birincioğlu \& Tekin, 2018: 170). In this sense, the concept of mushroom management is described as "people grow like mushrooms and keep in the dark and throw plenty of manure on them" (Herman, 1997: 66). It is a style of management where the employees cannot be involved in the decision-making process, the status of the organization. Additionally, this type of management cannot support of employees' curiosity and self-expression (Kılıç, 2015: 83). Moreover, managers commonly cannot desire to be interrogated and criticized by employees via continuing to keep their dominance and information on the one hand (Tekin \& Birincioğlu, 2017: 22).

Kılıç \& Olgun (2017: 107) emphasize that outrageous uncertainty is high and feedback is minimal in the mushroom management that can be defined as a big black hole where information, knowledge, and resources disappear. In other words, employees are working without knowing details about the organization's performance concerns and being kept in the dark for delaying a domino effect of key employee departures (www.workforcemanagementtoday.com, Date Retrieved: 03.10.2019). Similarly, Moore \& Sonsino (2007: 49) state that the combination of the science and art of keeping employees in the dark reveals mushroom management that is the most crucial reality about the impact on morale and retention. From this point of view, mushroom management is assumed as the opaque and unfair management style in which employees can be hold by managers without involving the organizational process, policies, and risks.

Taking into consideration of mushroom management style in which employees fly blind to organizational performance and are empowered without giving information about its purpose of the work, Geckoboard \& Censuswide (2015: 2) studied on more than 2000 employees from countries, the UK and US, and the impressive results regarding the impact of mushroom management are: 
M. K. Külekci - O. B. Özbozkurt - E. Bahar 12/1 (2020) 361-371

- The employees head for the door: $25 \%$ of employees have, or know someone who has, left an organization since they felt in the dark about the performance and direction of the company.

- Mistrust: More than 75\% of employees don't trust managers who do not share organizational data.

- A perception of power games: Over $25 \%$ of employees believe a lack of information stems from bosses playing power games.

- Detective work: Greater than half of employees resort to their own detective work to discover what's really going on in their company.

From this point of view, the following hypotheses and the conceptual model of the study are proposed:

$\mathrm{H}_{2}$ : Mushroom management has a positive impact on job stress.

$H_{3}$ : Mushroom management has a positive impact on intention to leave.

H4: Mushroom management mediates the link between job stress and intention to leave.

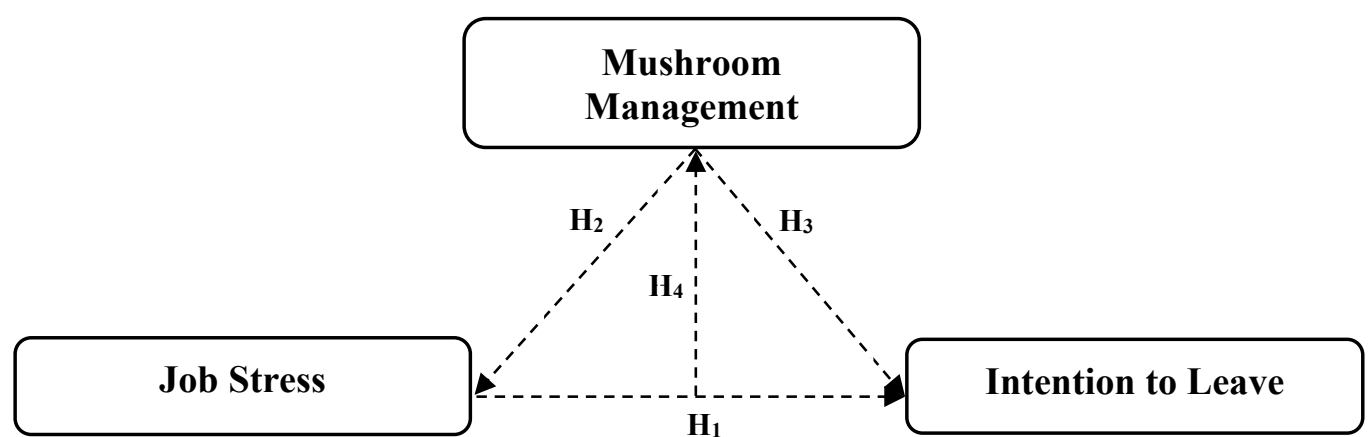

Figure 1. Conceptual Model

\section{METHODOLOGY}

\subsection{Sample and Data Collection}

The data was collected via using the convenience sampling method. Accordingly, the questionnaire was applied to 274 employees of the four different private hospitals in Tarsus, Mersin, representing half of the population (545 in total) of the study. Since the questionnaire was distributed to participants during their work, they were informed that their participation was voluntary; in this sense, responses would remain anonymous. Out of 274 responses, 235 were considerably returned; however, 221 responses were deemed appropriate for the analysis.

Taking into consideration of descriptive statistics of the sample in terms of age, gender, marital status, educational level, job experience, and household income, 17,2\% of participants were below 25 years, $43,9 \%$ of participants were between 26 and 35, 25,8\% of participants were between 36 and 45, and 13,1\% of participants were over 46 years. Additionally, 48,9\% of participants were female and 51,1\% of participants were male. Moreover, $50,2 \%$ of participants were married and $49,8 \%$ of participants were single. Also, $44,8 \%$ of participants had a high-school degree, $41,6 \%$ of participants had an undergraduate degree, and 13,6\% of participants had a postgraduate degree. In addition to that, $43,9 \%$ of participants had job experience below 5 years, 26,2\% of participants had job experience between 6 and 10 years, 17,2\% of participants had job experience between 11 and 15 years, and 12,7\% of participants had job experience over 16 years. Lastly, 23,5\% of participants had household income below $2.020 \mathrm{TL}, 29,9 \%$ of participants had household income between 2.021 and $3.000 \mathrm{TL}, 17,6 \%$ of participants had household income between 3.001 and $4.000,16,3 \%$ of participants had household income between 4.001 and 5.000, and 12,7\% participants had household income over 5.001 TL.

\subsection{Measures}

"Job Stress (JS)" was measured with the scale coined by Cohen, Kamarck \& Mermelstein (1983: 394-395) and adapted by Eskin, Harlak, Demirkıran \& Dereboy (2013: 138) which has 14 items and two dimensions 
M. K. Külekci - O. B. Özbozkurt - E. Bahar 12/1 (2020) 361-371

including "Perceived Insufficient Self-Efficacy (PISE) and Perceived Stress/Distress (PS/D)". Statements are based on the 5-point Likert scale from never (1) to always (5). Besides, the 4 -item scale developed by Rosin \& Korabik (1991: 330) and adapted by Elmas (2012: 10) was used to measure employees' level of "Intention to Leave (IL)" who work in the private healthcare sector. Respondents were asked to indicate the extent of their agreement with the statements on a 5 -point Likert scale ( $1=$ strongly disagree, $5=$ strongly agree). On the other hand, "Mushroom Management (MM)" was measured with the scale developed by Birincioğlu \& Tekin (2018: 185) which has 19 items and four dimensions including "Inadequate Information Sharing (IIS), Anxiety of Power Loss (APL), Inadequate Communication (IC), and Lack of Participatory Management (LPM)". Respondents were also asked to indicate the extent of their agreement with the statements on a 5-point Likert scale ( $1=$ strongly disagree, $5=$ strongly agree).

\subsection{Data Analysis}

In this study, Cronbach's alpha reliability coefficient test has been used to estimate the reliability and internal consistency of scale and its dimensions via using "SPSS 22.0" programme. Additionally, factor analysis has been used to examine the value of validity. Subsequently, the percentage of the variance of scale and its dimensions, Kaiser-Meyer-Olkin Measure of Sampling Adequacy (KMO) and Eigenvalue have been estimated. Furthermore, Correlation Analysis has been used to examine the relationship between dimensions and Hierarchical Regression Analysis has been used to explore the mediating role between variables. From this point of view, $p$ values considerably less than $p \leq 0,05$ have been acknowledged as statistically significant.

\section{RESULTS}

\subsection{Validity and Reliability}

In this study, Cronbach's Alpha Reliability Analysis has been tested to explore participants' degree of intention to leave, job stress, and mushroom management reliability and internal consistency levels. In this regard, Table 1 below demonstrates the scales and dimensions' reliability and validity values.

Table 1. The Scale's and its Dimensions' Reliability and Validity

\begin{tabular}{|c|c|c|c|c|}
\hline Dimensions & Number of Items & Variance & Cronbach's Alpha & KMO \\
\hline Intention to Leave & 4 & $52 \%$ & 0,90 & 0,88 \\
\hline Job Stress & 14 & & 0,91 & \multirow{3}{*}{0,90} \\
\hline Perceived Insufficient Self-Efficacy & 7 & $33 \%$ & 0,84 & \\
\hline Perceived Stress/Distress & 7 & $35 \%$ & 0,87 & \\
\hline Mushroom Management & 19 & & 0,91 & \multirow{5}{*}{0,88} \\
\hline Inadequate Information Sharing & 6 & $17 \%$ & 0,76 & \\
\hline Anxiety of Power Loss & 5 & $18 \%$ & 0,76 & \\
\hline Inadequate Communication & 4 & $18 \%$ & 0,75 & \\
\hline Lack of Participatory Management & 4 & $35 \%$ & 0,83 & \\
\hline
\end{tabular}

The results as reported in Table 1, the reliability coefficient of the intention to leave scale that has 4 items, has been seen 0,90 and it has been assumed as the scale is highly reliable. In addition to that, KMO value via using factor analysis has been determined as 0,88. Moreover, the results of Bartlett's test of sphericity that has been used to estimate the samples' equal variances, have shown that the dimensions of the scale are significant $(\mathrm{p}=0,01, \mathrm{p}<0,05)$. Precisely, the total variance explained of the intention to leave has been identified as $52 \%$.

Similarly, the reliability coefficient of the job stress scale that has 14 items and two dimensions (perceived insufficient self-efficacy and perceived stress/distress) has been signified as 0,91 . The estimated KMO value has been shown as 0,90 and for Bartlett Test, the scale and its dimensions are statistically significant $(\mathrm{p}=0,01$, $\mathrm{p}<0,05$ ). Moreover, the explained variance of two dimensions (perceived insufficient self-efficacy includes $33 \%$ and perceived stress/distress includes $35 \%$ ) of job stress scale contains $68 \%$ of the total variance. Considerably, the internal consistency of perceived insufficient self-efficacy has been estimated as 0,84 and perceived stress/distress has been determined as 0,87 .

By the same token, the reliability coefficient of the mushroom management scale that has 19 items and four dimensions (inadequate information sharing, anxiety of power loss, inadequate communication, and lack of 
participatory management) have been explored as 0,91 . Additionally, $\mathrm{KMO}$ value has been estimated as 0,88 and as Bartlett Test, the structure between dimensions is statistically significant $(p=0,01, p<0,05)$. Furthermore, the explained variance of the four dimensions of the mushroom management scale (inadequate information sharing includes $\% 17$, anxiety of power loss includes $\% 18$, inadequate communication includes $18 \%$, and lack of participatory management includes $35 \%$ ) contains $88 \%$ of the total variance. Also, the internal consistency of inadequate information sharing is 0,76 , anxiety of power loss is 0,76 , inadequate communication is 0,75 , and lack of participatory management is 0,83 .

\subsection{Hypothesis Testing}

After ensuring the validity and reliability, Table 2 below designates the relationship between intention to leave and job stress via using the Correlation Analysis.

Table 2. The Relationship between Intention to Leave and Job Stress

\begin{tabular}{lllcc}
\hline Scale/Dimension & Job Stress & $\begin{array}{l}\text { Perceived } \\
\text { Self-Efficacy }\end{array}$ & Insufficient & Perceived Stress/Distress \\
\hline Intention to Leave & $\mathrm{r}$ & $0,271^{*}$ & $0,169^{*}$ & $0,307^{*}$ \\
& $\mathrm{p}$ & 0,01 & 0,01 & 0,01 \\
\hline
\end{tabular}

The results as demonstrated in Table 2, there is a weak positive correlation between the participants' intention to leave and the level of job stress and in this sense, it has been assumed as statistically significant ( $r=0,271$, $\mathrm{p}=0,01, \mathrm{p}<0,05)$. Similarly, there is a weak positive correlation between the participants' intention to leave and perceived insufficient self-efficacy $(\mathrm{r}=0,169, \mathrm{p}=0,01, \mathrm{p}<0,05)$ and perceived stress/distress $(\mathrm{r}=0,307, \mathrm{p}=0,01$, $\mathrm{p}<0,05)$. From this point of view, it has been interpreted that the increase of participants' job stress, perceived insufficient self-efficacy, and perceived stress/distress level have an impact on increasing the level of intention to leave. From this point of view, Hypothesis 1 has been accepted. On the other hand, Table 3 below indicates the relationship between mushroom management, intention to leave and job stress via using the Correlation Analysis.

Table 3. The Relationship between Mushroom Management, Intention to Leave and Job Stress

\begin{tabular}{llllcc}
\hline Scale/Dimensions & & $\begin{array}{l}\text { Intention } \\
\text { to Leave }\end{array}$ & $\begin{array}{l}\text { Job } \\
\text { Stress }\end{array}$ & $\begin{array}{l}\text { Perceived Insufficient } \\
\text { Self-Efficacy }\end{array}$ & Perceived Stress/Distress \\
\hline Mushroom & $\mathrm{r}$ & $0,464^{*}$ & $0,223^{*}$ & $0,183^{*}$ & $0,250^{*}$ \\
Management & $\mathrm{p}$ & 0,01 & 0,01 & 0,01 & 0,01 \\
\hline Inadequate & $\mathrm{r}$ & $0,267^{*}$ & 0,13 & 0,08 & 0,07 \\
Information Sharing & $\mathrm{p}$ & 0,01 & 0,06 & 0,24 & 0,29 \\
\hline Anxiety of Power & $\mathrm{r}$ & $0,470^{*}$ & $0,246^{*}$ & $0,202^{*}$ & $0,278^{*}$ \\
Loss & $\mathrm{p}$ & 0,01 & 0,01 & 0,01 & 0,01 \\
\hline Inadequate & $\mathrm{r}$ & $0,349^{*}$ & $0,210^{*}$ & $0,204^{*}$ & $0,213^{*}$ \\
Communication & $\mathrm{p}$ & 0,01 & 0,01 & 0,01 & 0,01 \\
\hline Lack of Participatory & $\mathrm{r}$ & $0,439^{*}$ & $0,160^{*}$ & $0,133^{*}$ & $0,178^{*}$ \\
Management & $\mathrm{p}$ & 0,01 & 0,02 & 0,04 & 0,01 \\
\hline
\end{tabular}

As shown in Table 3, there is a moderate positive correlation between mushroom management and intention to leave $(\mathrm{r}=0,464, \mathrm{p}=0,01, \mathrm{p}<0,05)$. Additionally, it has been seen that there is a weak positive correlation between mushroom management and job stress $(\mathrm{r}=0,223, \mathrm{p}=0,01, \mathrm{p}<0,05)$ and job stress dimensions which are perceived insufficient self-efficacy $(\mathrm{r}=0,183, \mathrm{p}=0,01, \mathrm{p}<0,05)$ and perceived stress/distress $(\mathrm{r}=0,250, \mathrm{p}=0,01$, $\mathrm{p}<0,05)$. Moreover, there is a weak positive correlation between the dimension of inadequate information sharing and the intention to leave $(\mathrm{r}=0,267, \mathrm{p}=0,01, \mathrm{p}<0,05)$. However, inadequate information sharing has statistically insignificant effect on job stress $(\mathrm{r}=0,13, \mathrm{p}=0,06, \mathrm{p}>0,05)$ and its dimensions that are perceived insufficient self-efficacy $(\mathrm{r}=0,08, \mathrm{p}=0,24, \mathrm{p}>0,05)$ and perceived stress/distress $(\mathrm{r}=0,07, \mathrm{p}=0,29, \mathrm{p}>0,05)$. Furthermore, there is a moderate positive correlation between anxiety of power loss and intention to leave $(\mathrm{r}=0,470, \mathrm{p}=0,01, \mathrm{p}<0,05)$. Precisely, it has been seen that there is a weak positive correlation between anxiety of power loss and job stress $(r=0,246, p=0,01, p<0,05)$ and its dimensions which are perceived insufficient self- 
M. K. Külekci - O. B. Özbozkurt - E. Bahar 12/1 (2020) 361-371

efficacy $(\mathrm{r}=0,202, \mathrm{p}=0,01, \mathrm{p}<0,05)$ and perceived stress/distress $(\mathrm{r}=0,278, \mathrm{p}=0,01, \mathrm{p}<0,05)$. In addition to that, there is a weak positive correlation between inadequate communication and intention to leave $(r=0,349, p=0,01$, $\mathrm{p}<0,05)$, job stress $(\mathrm{r}=0,210, \mathrm{p}=0,01, \mathrm{p}<0,05)$ and its dimensions that are perceived insufficient self-efficacy $(\mathrm{r}=0,204, \mathrm{p}=0,01, \mathrm{p}<0,05)$ and perceived stress/distress $(\mathrm{r}=0,213, \mathrm{p}=0,01, \mathrm{p}<0,05)$. Besides, there is a moderate positive correlation between lack of participatory management and intention to leave $(r=0,439, p=0,01, p<0,05)$. Lately, there is a weak positive correlation between lack of participatory management and job stress $(\mathrm{r}=0,160$, $\mathrm{p}=0,01, \mathrm{p}<0,05)$ and its dimensions which are perceived insufficient self-efficacy $(\mathrm{r}=0,133, \mathrm{p}=0,01, \mathrm{p}<0,05)$ and perceived stress/distress $(\mathrm{r}=0,178, \mathrm{p}=0,01, \mathrm{p}<0,05)$. From this point of view, mushroom management has a statistically significant effect on both job stress and intention to leave. In this regard, Hypothesis 2 and Hypothesis 3 have been accepted for this study. On the other hand, Table 4 below indicates the mediating role of mushroom management within the impact of job stress on intention to leave via using the Hierarchical Regression Analysis.

Table 4. The Mediating Role of Mushroom Management Within the Impact of Job Stress on Intention to Leave

\begin{tabular}{|c|c|c|c|c|c|c|c|c|c|c|}
\hline \multirow[b]{2}{*}{ Model } & \multirow[b]{2}{*}{$\begin{array}{l}\text { Dependent } \\
\text { Variable }\end{array}$} & \multirow[b]{2}{*}{$R^{2}$} & \multicolumn{3}{|c|}{ Independent Variables } & \multicolumn{5}{|c|}{ Mediator Variables } \\
\hline & & & $J S$ & PISE & $P S / D$ & $M M$ & IIS & $A P L$ & IC & $L P M$ \\
\hline & & & $\beta$ & & & & & & & \\
\hline $\begin{array}{l}\text { Model } \\
1\end{array}$ & IL & 0,30 & $\begin{array}{l}0,17 \\
(0,03)^{*}\end{array}$ & $\begin{array}{l}0,07 \\
-0,62\end{array}$ & $\begin{array}{l}0,31 \\
(0,01)^{*}\end{array}$ & & & & & \\
\hline $\begin{array}{l}\text { Model } \\
2 \\
\text { (Media } \\
\text { ting } \\
\text { Role) } \\
\end{array}$ & IL & 0,53 & $\begin{array}{l}0,84 \\
(0,01)^{*}\end{array}$ & $\begin{array}{l}0,08 \\
(0,04)^{*}\end{array}$ & $\begin{array}{l}0,64 \\
(0,01)^{*}\end{array}$ & $\begin{array}{l}0,22 \\
(0,02)^{*}\end{array}$ & $\begin{array}{l}0,03 \\
0,93\end{array}$ & $\begin{array}{l}0,02 \\
0,97\end{array}$ & $\begin{array}{l}0,01 \\
0,99\end{array}$ & $\begin{array}{l}0,41 \\
(0,01)^{*}\end{array}$ \\
\hline \multicolumn{11}{|c|}{$\Delta R^{2}=0,23, p<0,05$} \\
\hline
\end{tabular}

As Table 4 demonstrates that, in Model 1, the job stress dimensions have a partial mediating role in the relationship between job stress and intention to leave $(p<0,05)$. In addition to that, it has been explored that job stress, perceived stress/distress have a statistically positive relationship with intention to leave and it has been identified that job stress' ability to explain the changes on intention to leave is $0,30\left(R^{2}=\% 30\right)$. Besides, since the coefficient of perceived insufficient self-efficacy is statistically insignificant, it does not seem in Model 1 $(\mathrm{p}>0,05)$. Taking into consideration of Model 1 , it has been presumed as statistically significant for this study $(\mathrm{F}=20,80, \mathrm{p}=0,01, \mathrm{p}<0,05)$.

By the same token, mushroom management scale and its dimensions have been included in Model 2 and it has been identified that $R^{2}$ is 0,53 (increased 0,23$)$ and statistically significant $\left(\Delta R^{2}=0,23, p<0,05\right)$. From this point of view, the increase of $\mathrm{R}^{2}$ has been explained as mushroom management scale and its dimensions create a mediating effect in Model 2. On the other hand, the mediator variables which are inadequate information sharing, anxiety of power loss, and inadequate communication are statistically insignificant; thus, they have not been included in Model 2. In this respect, it has been seen that Model 2 is statistically significant for this study $(\mathrm{F}=22,84, \mathrm{p}=0,01, \mathrm{p}<0,05)$.

Considerably, the main reason for the increase in job stress and perceived stress/distress values is the effect of job stress on intention to leave. In addition to that, to be included in mushroom management scale and lack of participatory management in Model 2, is an indicator of the mediator effect. Precisely, the mushroom management has a mediating role owing to increasing of $R^{2}$ measurement in the Model $2(p<0,05)$. Moreover, the Sobel Test results have shown that mushroom management and lack of participatory management have a mediating effect between the variables $(z=3,15, p=0,01, p<0,05)$.

Lastly, it has been determined that the fundamental variable of effecting on intention to leave is job stress $(\beta=0,84)$. Additionally, it has been seen that the effect variables are respectively perceived stress/distress $(\beta=0,64)$, lack of participatory management $(\beta=0,44)$, mushroom management $(\beta=0,21)$, and perceived insufficient self-efficacy $(\beta=0,08)$. Therefore, Hypothesis 4 has also been accepted for this study. 


\section{CONCLUSION}

Poor management practices of managers via keeping employees dark such as mushrooms lead employee's job stress and intention to leave and these variables have been regarded to be a vital issue and major concern for any organization from all over the world. In this respect, the present study aimed at exploring the mediating role played by mushroom management style within the impact of job stress on intention to leave and fulfilling the research gap in the related literature, it has been identified that job stress has a significant effect on intention to leave which has similar results with previous studies (Arshadi \& Damiri, 2013: 708; Fong \& Mahfar, 2013: 33; Hwang, Lee, Park, Chang \& Kim, 2014: 61; Mxenge, Dywili \& Bazana, 2014: 13; Suarthana \& Riana, 2016: 721; Gök et al., 2017: 23; Lee \& Jang, 2019: 13).

Moreover, mushroom management has a statistically significant effect on both job stress and intention to leave. The fundamental reason for this, employees might more likely to be skeptical and discover what's really going on in their company instead of focusing their own job owing to being exposed to mushroom management, and it creates job stress and in turn, causes intention to leave. Additionally, the mushroom management has a mediating role on within the impact of job stress on intention to leave since the mushroom management might come up with many negative consequences such as less confidence in managers who are secretive with data and in turn, constitutes mistrust that increase current job stress within the impact on intention to leave. Thus, the hypotheses of this study were corroborated, as expected.

On the other hand, taking into consideration the results of this study, the recommendations are twofold: for researchers and managers. Firstly, researchers should concentrate more on quantitative studies regarding mushroom management by involving different variables to contribute to the research gap. Besides, it is recommended to managers pay more attention to encouraging an effective and operative communication throughout the organization and regularly share more information with the employee, since they have a significant role in achieving organizational goals; namely, effectiveness. Furthermore, implementing the participative management strategies and policies, which in turn will increase the employees' intention to stay on the contrary to leave.

\section{REFERENCES}

Abbasi, S. G. (2018). Leadership styles: Moderating Impact on Job Stress and Health. Journal of Human Resources Management Research, 1-11.

Akanji, B. (2013). Occupational Stress: A Review on Conceptualisations, Causes and Cure. Economic InsightsTrends and Challenges, 2, 73-80.

Atterwall, H., \& Engqvist, A. (2016). To Cope with Role Conflict and Work Stress. A middle managerial perspective. (Master's Thesis within Business Administration. Jönköping University).

Appollis, V. P. (2010). The Relationship Between Intention to Quit, Pyschological Capital And Job Satisfaction in The Tourism Industry in the Western Cape (Doctoral dissertation, University of the Western Cape).

Arshadi, N., \& Damiri, H. (2013). The Relationship of Job Stress with Turnover Intention and Job Performance: Moderating role of OBSE. Procedia-Social and Behavioral Sciences, 84, 706-710.

Barling, J., Kelloway, E. K., \& Frone, M. R. (2004). Handbook of Work Stress. Sage Publications.

Birincioğlu, N., \& Tekin, E. (2018). Mantar Yönetim Ölçeği Geliştirilmesi Üzerine Bir Çalışma. Business and Economics Research Journal, 9(1), 169-186.

Blaug, R., Kenyon, A., \& Lekhi, R. (2007). Stress at Work. The Work Foundation, London.

Burman, R., \& Goswami, T. G. (2018). A Systematic Literature Review of Work Stress. International Journal of Management Studies, 3(9), 112-132.

Cohen, S., Kamarck, T., \& Mermelstein, R. (1983). A Global Measure of Perceived Stress. Journal of Health and Social Behavior, 385-396. 
M. K. Külekci - O. B. Özbozkurt - E. Bahar 12/1 (2020) 361-371

Da Costa, B. R. C., \& Pinto, I. C. J. F. (2017). Stress, Burnout and Coping in Health Professionals: A Literature Review. Journal of Psychology Brain Studies, 1(1), 1-8.

Elmas, S. (2012). İşyerinde Mobbing ve Çalışanların İşten Ayrılma Niyeti Üzerine Etkilerine İlişkin Bir Araştırma. İstanbul Üniversitesi: Yüksek Lisans Tezi.

Eskin, M., Harlak, H., Demirkıran, F., \& Dereboy, Ç. (2013). Algılanan Stres Ölçeğinin Türkçe'ye Uyarlanması: Güvenirlik ve Geçerlik Analizi. New Symposium Journal, 51(3),132-140.

Fong, Y. L., \& Mahfar, M. (2013). Relationship Between Occupational Stress and Turnover Intention among Employees in A Furniture Manufacturing Company in Selangor. Sains Humanika, 64(1), 33-39.

Ganster, D. C., \& Schaubroeck, J. (1991). Work Stress and Employee Health. Journal of Management, 17(2), 235271.

Gaudenz, C., De Geest, S., Schwendimann, R., \& Zúñiga, F. (2017). Factors Associated with Care Workers' Intention to Leave Employment in Nursing Homes: A Secondary Data Analysis of the Swiss Nursing Homes Human Resources Project. Journal of Applied Gerontology, 1-27.

Geckoboard \& Censuswide. (2015). Mushroom Management Leaves Employees Heading For The Door, Research Report. https://www.geckoboard.com/learn/guides/mushroom-management/

Gök, Ö. A., Akgündüz, Y., \& Alkan, C. (2017). The Effects of Job Stress and Perceived Organizational Support on Turnover Intentions of Hotel Employees. Journal of Tourismology, 3(2), 23-32.

Gupta, M., \& Shaheen, M. (2017). Impact of Work Engagement on Turnover Intention: Moderation by Psychological Capital in India. Business: Theory and Practice, 18, 136-143.

Harshana, P. V. S. (2018). Work-Related Stress: A Literature Review. Annals of Social Sciences \& Management Studies, 2(3), 59-65.

Herman, R. E. (1997). The Process of Excelling: The Practical How-to Guide for Managers and Supervisors Greensboro, NC: Oakhill Press.

Hwang, J., Lee, J. J., Park, S., Chang, H., \& Kim, S. S. (2014). The impact of occupational stress on employee's turnover intention in the luxury hotel segment. International Journal of Hospitality $\mathcal{E}$ Tourism Administration, 15(1), 60-77.

Kashmoola, B., Ahmad, F., \& Kheng, Y. K. (2017). Job Satisfaction and Intention to Leave in SME Construction Companies of United Arab Emirates (UAE). Business Management Dynamics, 7(3), 1-9.

Kılıç, T. (2015). Mushroom Management Theory; Sample of Health Sector. Academy of Strategic Management Journal, 14, 83-89.

Kılıç, T., \& Olgun, H. (2017). Mantar Yönetim Yaklaşımı. Örgütsel Davranış Araştırmaları Dergisi, 2(2), 105-113.

Lee, E., \& Jang, I. (2019). Nurses' Fatigue, Job Stress, Organizational Culture, and Turnover Intention: A Culture-Work-Health Model. Western Journal of Nursing Research,1-16.

Liu, J., Zhu, B., Wu, J., \& Mao, Y. (2019). Job satisfaction, Work Stress, And Turnover Intentions among Rural Health Workers: A Cross-Sectional Study in 11 Western Provinces of China. BMC Family Practice, 20(1), $1-11$.

Lo, W. Y., Chien, L. Y., Hwang, F. M., Huang, N., \& Chiou, S. T. (2018). From Job Stress to Intention to Leave among Hospital Nurses: A Structural Equation Modelling Approach. Journal of Advanced Nursing, 74(3), 677-688.

Lu, Y., Hu, X. M., Huang, X. L., Zhuang, X. D., Guo, P., Feng, L. F., Hu, W., Chen, L., Zou, H. \& Hao, Y. T. (2017). The Relationship between Job Satisfaction, Work Stress, Work-Family Conflict, and Turnover Intention Among Physicians in Guangdong, China: A Cross-Sectional Study. BMJ Open, 7(5), 1-12.

Manjunatha, M. K., \& Renukamurthy, T. P. (2017). Stress among Banking Employee-A Literature Review. International Journal of Research-Granthaalayah, 5, 206-213. 
M. K. Külekci - O. B. Özbozkurt - E. Bahar 12/1 (2020) 361-371

Michie, S. (2002). Causes and Management of Stress at Work. Occupational and Environmental Medicine, 59(1), 67-72.

Mohajan, H.K. (2012). The Occupational Stress and Risk of it among the Employees. International Journal of Mainstream Social Science, 2(2): 17-34.

Moore, J., \& Sonsino, S. (2007). The Seven Failings of Really Useless Leaders. London: MSL Publishing.

Mosadeghrad, A. M. (2013). Occupational Stress and Turnover Intention: Implications for Nursing Management. International Journal of Health Policy and Management, 1(2), 169-176.

Munisamy, S. (2013). Identifying factors that Influences Job Performance Amongst Employees in Oil Palm Plantation. Project Paper of Bachelor degree in Psychology, Open University Malaysia.

Mxenge, S. V., Dywili, M., \& Bazana, S. (2014). Organisational Stress and Employees' Intention to Quit Amongst Administrative Personnel at the University of Fort Hare, Eastern Cape, South Africa. International Journal of Research in Social Sciences, 4(5), 13-29.

Özbozkurt, O. B. \& Özbozkurt, N. (2019). Rol Belirsizliği ve Rol Çatışmasının İş Performansına Etkisinde İş Tatmininin Aracılık Rolü: Mersin İlinde Faaliyette Bulunan Özel Hastaneler Üzerine Bir Araştırma. Anemon Muş Alparslan Üniversitesi Sosyal Bilimler Dergisi, 7(4), 307-314.

Radzi, S. M., Ramley, S. Z., Salehuddin, M., Othman, Z., \& Jalis, M. H. (2009). An Empirical Assessment of Hotel Departmental Managers Turnover Intentions: The Impact of Organizational Justice. International Journal of Business and Management, 4(8), 173-183.

Ramamurthi, K., Vakilbashi, A., Rashid, S. Z. A., Mokhber, M., \& Basiruddin, R. (2016). Impact of Job Stressors Factors on Employees' Intention to Leave Mediated by Job Engagement and Dispositional Factors. International Review of Management and Marketing, 6(3), 528-531.

Ratnawat, R. G., \& Jha, P. C. (2014). Impact of Job-Related Stress on Employee Performance: A Review and Research Agenda. Journal of Business and Management, 16(11), 1-16.

Rengin, K. (2018). Stress Management among Nurses: A Literature Review of the Causes and Coping Strategies (Doctoral dissertation, Bachelor's Thesis. Degree Programme in Nursing. Arcada University of Applied Science).

Rosin, H. M., \& Korabik, K. (1991). Workplace variables, affective responses, and intention to Leave Among Women Managers. Journal of Occupational Psychology, 64(4), 317-330.

Shahsavarani, A. M., Azad Marz Abadi, E., \& Hakimi Kalkhoran, M. (2015). Stress: Facts and Theories through Literature Review. International Journal of Medical Reviews, 2(2), 230-241.

Suarthana, J. H. P., \& Riana, I. G. (2016). The Effect of Psychological Contract Breach and Workload on Intention to Leave: Mediating Role of Job Stress. Procedia-Social and Behavioral Sciences, 219, 717-723.

Şener, G. ve Gündüzalp, S. (2019). Okul Yöneticilerinin Benimsedikleri Mantar Yönetim Yaklaşımı ile Okul Liderliği Arasındaki İlişkinin İncelenmesi, VIth International Eurasian Educational Research Congress, 19-22 Haziran, Ankara.

Tekin, E. \& Birincioğlu, N. (2017). Bilgi Çağının Odak Noktası Üniversitelerde Mantar Yönetimi. International Journal of Academic Value Studies, 3(14), 22-29.

Tett, R. P., \& Meyer, J. P. (1993). Job Satisfaction, Organizational Commitment, Turnover Intention, and Turnover: Path Analyses Based on Meta-Analytic Findings. Personnel Psychology, 46(2), 259-293.

Treglown, L., Zivkov, K., Zarola, A., \& Furnham, A. (2018). Intention to Quit and the Role of Dark Personality and Perceived Organizational Support: A Moderation and Mediation Model. Plos One, 13(3), 1-13.

Worku, N., Feleke, A., Debie, A., \& Nigusie, A. (2019). Magnitude of Intention to Leave and Associated Factors among Health Workers Working at Primary Hospitals of North Gondar Zone, Northwest Ethiopia: Mixed Methods. Biomed Research International, 1-9. 
M. K. Külekci - O. B. Özbozkurt - E. Bahar 12/1 (2020) 361-371

Yan, H., \& Xie, S. (2016). How Does Auditors' Work Stress Affect Audit Quality? Empirical Evidence from The Chinese Stock Market. China Journal of Accounting Research, 9(4), 305-319.

Zahra, S. S., Khan, M. I., Imran, M., Aman, Q., \& Ali, R. (2018). The Relationship Between Job Stress and Turnover Intentions in the Pesticide Sector of Pakistan: An Employee Behavior Perspective. Management Issues in Healthcare System, 4, 1-12.

https://www.workforcemanagementtoday.com/articles/418940-study-highlights-perils-mushroommanagement.htm, Date Retrieved: 03.10.2019 